\title{
Five Years Beyond Sendai-Can We Get Beyond Frameworks?
}

\author{
Ben Wisner ${ }^{1}$
}

Published online: 9 April 2020

(C) The Author(s) 2020

\begin{abstract}
The Sendai Framework for Disaster Risk Reduction 2015-2030 (SFDRR) and its implementation is evaluated after its first five years. A dozen questions that the author and a colleague used in their evaluation of the Hyogo Framework for Action 2005-2015 (HFA) are repeated. Improvements are noted in relation to possible coherence and alignment with other components of the Post-2015 Agenda, especially as regards climate change and urban disasters as well as the higher visibility of civil society and women, and also regarding the specificity of targets and monitoring of governments' successes. Nevertheless, the overall conclusion is that both the HFA and the SFDRR fail to deal with root causes of disaster. A new, radically proactive leadership role is suggested for the United Nations Office for Disaster Risk Reduction in partnership with civil society in identifying and warning all engaged in Post-2015 Agenda activities of possible creation of new risk by agenda implementation activities, especially for the poor and already-marginalized.
\end{abstract}

Keywords Civil society - Climate change - Disaster risk reduction - Hyogo framework - Sendai framework

\section{Introduction}

In 2005, I co-authored a report called Beyond Kobe ${ }^{1}$ and subsequently published a paper based on that report (Wisner and Walker 2005a, b). My co-author, Peter

Ben Wisner

bwisner@igc.org

1 Institute for Risk and Disaster Reduction, University College London, London WC1E 6BT, UK
Walker, and I reflected on the meeting that gave birth to the Hyogo Framework for Action (HFA). I turn my attention now to the Sendai Framework for Disaster Reduction (SFDRR), child of Kobe (parentage unknown ${ }^{2}$ ), after five years of implementation. I ask the same "Dozen Big Questions" we originally asked about Kobe and the framework for action created at the international gathering at Kobe.

\subsection{Global Context}

2005 might be thought of as "the year of natural disasters" wrote an information officer at the World Health Organization (Braine 2006). There were earthquakes in Pakistan and India, a volcanic eruption and landslides in Nicaragua, Hurricane Katrina in the United States, and a locust attack and drought in Niger. Immediately before all this disruption, the atmosphere in the conference that crafted the Hyogo Framework was dominated by the recent loss of life in the Indian Ocean tsunami of 26 December 2004. By contrast, the year the SFDRR was agreed, delegates and others in that Japanese city were reminded of the 2011 Tohoku earthquake and tsunami disaster in Japan and

\footnotetext{
${ }^{1}$ I will use "Kobe" as short hand for the World Conference on Disaster Reduction, held in Kobe, Japan, 18-22 January 2005 (https:// www.unisdr.org/2005/wcdr/wcdr-index.htm) and also for the agreement that emerged, the Hyogo Framework of Action 2005-2015, herein after "HFA" (https://www.unisdr.org/we/coordinate/hfa). Details of HFA's successor, the Sendai Framework for Disaster Risk Reduction 2015-2030, herein after "SFDRR" are available at https:// www.undrr.org/.

${ }^{2}$ Rumor suggests the father could have been Fukushima Dai Ichi.
} 
subsequent nuclear disaster at Fukushima Dai $\mathrm{Ichi}^{3}$; although surely many were still thinking about the catastrophic earthquake in Haiti (2010) and recent damage from Cyclone Pam (March 2015).

Geopolitically and economically, 2005 and 2015 were worlds apart. The near-worldwide economic crisis of 2007-2008 stands as a major watershed between the two UN global platforms on disaster reduction (Economist 2013). Austerity and increased precariousness of employment became common in many countries, and these situations increased the vulnerability of people to a variety of additional shocks and crises as pensions, disability assistance, and other elements in social safety nets were reduced in many countries, and as the knock-on effects of recession rippled through the economies of poor and highly indebted countries. Global politics were also different (Lindsay 2015). Instability was increasing. Civil wars became increasingly internationalized when Saudi Arabia became involved in the war in Yemen, as did Russia in the civil war in Syria. Europe was dealing with a million immigrants and refugees from these and other conflicts and from countries where livelihoods had collapsed. Also, notably, and on the plus side, an agreement to reduce greenhouse gas climate warming emissions was finally signed in Paris later in 2015.

\subsection{Words Matter}

Before proceeding to interrogate the SFDRR, I need to stake out a position regarding words. When I ask in the subtitle_-Can we get beyond frameworks?"-in part I am suggesting that language one takes for granted may cage and imprison thought and imagination. Should we not take a critical step back from mottos, oft-repeated phrases, neologisms, and metaphors that may serve as prison bars, walls, and jailors? UN- and international nongovernmental organization (INGO)-speak are rife with such words. ${ }^{4}$

For example, does the phrase "disaster risk reduction" not distract attention from disaster risk creation? Might not some of the many meanings of the word "resilience" imply saddling ordinary people, often the most vulnerable and marginal, with responsibility to follow instructions, behave obediently, and be responsible for their own safety? Are these same people not stigmatized as lazy, non-adopters, resistant, even superstitious during disaster recovery if they question authority, and even more so, if residents resist relocation (Jerolleman 2019)?

\footnotetext{
${ }^{3}$ Japan was understandably proud of the recovery of Kobe following the 1995 Great Hanchin Earthquake, and therefore hosted the 2005 Kobe conference. Likewise, Japan was keen to showcase recovery from the Tohoku events by hosting the 2015 conference in Sendai.

4 I employ metaphor ("prison," "bars") to raise awareness of the danger of metaphors, not because any language other than mathematics is free of them!
}

So, words matter, and what pops out immediately from SFDRR documents is the word "dividend." The latest global platform proceedings states, "The theme of GP2019-'Resilience Dividend: Towards Sustainable and Inclusive Societies' - focused on how managing disaster risk and scaling up risk-informed development investments pay dividends in multiple sectors and geographies. It encompasses more than just economic profit, it continues to reduce disaster risk and strengthens outcomes across the social, economic, financial and environmental sectors in the long term" (UNDRR 2019a, p. 5). Despite its vague gesturing toward "inclusive and sustainable societies" and denial of a primary focus on "economic profit," what "dividend" means is that costs to the state are avoided: cost of replacing infrastructure and providing aid to people who have suffered. Losses to the economy are avoided or reduced. ${ }^{5}$ Also, some businesses benefit, especially due to regulatory changes pushed through legislatures in the wake of the "shock" of the disaster, as they were in Puerto Rico after Hurricane Maria (Klein 2008, 2018).

Unreflective use of the word "dividend" by the Sendai Framework's proponents causes me to wonder if the global platform meeting that reviewed the progress of the SFDRR held in Geneva in 2019 was in the wrong Swiss city. Should it not have been Davos, site of the World Economic Summit? Thus, the phrase in my subtitle, "Can we get beyond," means beyond the prison of received and hegemonic language that obscures and hides the root causes of disaster. In doing so, and taking a fresh look, can we possibly help to make unnecessary yet more frameworks for disaster reduction, a grandchild and even a great grandchild of Kobe and the HFA?

\section{Kobe Looks Fondly But Sternly at her Child}

In Beyond Kobe we asked five questions concerning the understanding of disasters and seven concerning possible ways forward for turning that understanding into action. I return to those questions and direct them at the SFDRR. The conclusion is that while there have been improvements, the SFDRR remains strikingly oblivious to root causes of disaster-the same flaw that affected the HFA.

\subsection{Questions Concerning Our Understanding of Disasters}

There is enough knowledge. This was true before Kobe and is certainly true 30 years after the beginning of the first International Decade for Natural Disaster Reduction (UNDRR 2020a).

\footnotetext{
${ }^{5}$ Compare World Bank (2010).
} 
What do we know for sure? ${ }^{6}$

Disasters are not "natural" (O'Keefe et al. 1976; Chmutina and von Meding 2019). The conventional and common-sense notion of a "natural" disaster is wrong and misleading. A harmful physical process or event can have a natural (earth-based, atmospheric, or space-based) component, but vulnerable (that is, unprotected) people have to be exposed. We also know that vulnerability is situational, not a permanent characteristic or property of some humans and not others. Vulnerable people are made vulnerable by deeply rooted social processes. People with power in society, and the institutions that wield and channel that power, can reduce or increase the burden of vulnerability or shift it from one group to another through policy decisions. Many of these policies have to do with domains not conventionally considered to belong to what has become known as "disaster risk reduction" (DRR). "Emergency management" and "disaster risk management" are yet narrower domains of conventional understanding and practice.

What the experience of 10 years working all over the world at scales from local to global under the overall guidance of the Hyogo Framework shows is that reduction of loss, injury, and death from natural hazards requires a comprehensive, whole society approach that engages all domains that touch people's lives: education, health care, food and nutrition, sanitation, water supply, shelter, livelihoods and employment, mobility and infrastructure, energy, law, and government institutions.

In principle, the Sendai Framework began with a head start. We knew all this. In theory, synergistic and comprehensive implementation could be achieved through bundling the SFDRR's targets together with the sustainable development goals (SDGs) and with efforts to address climate change and assist adaptation to its inevitable effects, as well as reforms in the systems of humanitarian assistance, development financing, and urban management. In fact, this tantalizing possibility of coordination, alignment, and coherence takes the form of a series of post-2015 initiatives and frameworks negotiated separately, but all echoing the vision in the report commissioned by the then UN Secretary General, "A Life of Dignity for All" (UN 2013).

There are seven post-2015 initiatives. The dynamics of geopolitics and intra and interagency politics will determine whether they will be seen post-2030 as a powerful team that did, in fact, provide that promised life of dignity (and security) and be remembered as "the Seven Samurai." Indeed, policy analysts see synergism among various post-

\footnotetext{
${ }^{6}$ The research base for these generalizations is very large; see, among others, Wisner et al. (2004), Wisner et al. (2012), Tierney (2014), (Oliver-Smith 2016).
}

2015 agreements as vital to the success of all of them (Peters and Tanner 2016; Saunders 2020). Without commitment, coordination, and action on the ground, however, they could be remembered as bumbling clowns fighting over funding and prestige and accomplishing little, and therefore remembered as "the Seven Dwarfs":

- Sustainable Human Development (the Sustainable Development Goals);

- The Paris Agreement (within the UNFCCC: the UN Framework Convention on Climate Change);

- Addis Ababa Action Agenda (Financing for Development);

- The World Humanitarian Summit;

- The New Urban Agenda;

- Various regional Peace and Security Initiatives. ${ }^{7}$

The Sendai Framework started off with fully digested knowledge and experience of several decades of common efforts on behalf of enabling that "life with dignity for all." Since the questions Peter Walker and I asked about the HFA were based in precisely that comprehensive understanding of development and disasters, it is fair to ask the same questions of the SFDRR.

\subsection{Questions about Governance and Respect for People's Rights in the Hyogo and Sendai Frameworks}

In Beyond Kobe we began by asking about government institutions, political will, inclusion and recognition of a human right to avoidable harm in natural hazard events or a human right to disaster mitigation and relief $^{8}$ for everyone (Wisner and Walker 2005a). Recalling that the Indian Ocean tsunami profoundly affected how delegates, representatives, and experts at the Kobe Conference approached disaster, we noted that an effectively failed state such as was found in Somalia could not warn its coastal residents of the tsunami, whereas farther south on the same affected coast, Kenya and Tanzania had the capacity to issue a warning.

Likewise, in 2010, the extremely weak and corrupt Haitian state was unable to assist the multitudes who suffered in the 2010 earthquake, and this fact was carried

\footnotetext{
7 The seventh is not a single global initiative or agreement like the other six, but a series of conflict resolution and peace-making initiatives that recognize that reduction of violent conflict and peaceful settlement of disputes are a precondition for progress in the other six areas (see, for example, Kashambuzi 2013).

${ }^{8}$ Human rights may be thought of as in relation to the duty of care incumbent on a state and also in less ambitious terms as the human right of the disaster affected to assistance (see: Kent 2001; Saechao 2007). These issues overlap with conceptions of human rights implied debates over the right to compensation for loss and damage associated with climate change. For example, see (Vogler 2017).
} 
forward into deliberations preparing for the world conference in Sendai and the Sendai Framework itself (UNISDR 2011a, 2015). The issue of stability and responsiveness of the state remained the core challenge. Throughout the HFA's 10 years, civil society and experts called on central governments to decentralize the financial and technical means for local government units to engage in partnerships with civil society and local groups of risk bearers. ${ }^{9}$ Most so-called decentralization under the SFDRR remains rhetorical or controlled rigidly by upwards accountability to the central state or, alternatively, to a donor country or international nongovernmental organization (Potetee and Ribot 2011; Gibson 2019). "Project-ism" is still the dominant mode of top-down DRR and plans, protocols and "log frame" choreography still blunt attempts to mesh with people's skill and local knowledge to produce flexible, localized assistance.

\subsection{Globalization and Disasters in the Hyogo and Sendai Frameworks}

What governments vet proposed investments, or require and enforce safeguards against the creation of new risks? What incentives, pressures, or institutional arrangements increase the chance that governments will screen proposed overseas direct investment from the point of view of ordinary people's welfare for whom government has a duty of care and with whom a social contract?

Hyogo Framework. The Beyond Kobe assessment asked whether implementing the HFA would address concerns voiced by civil society and researchers over the impact of overseas direct investment on risk creation. Risk "creation" is used here in the sense of new or enhanced risk resulting from risk-blind investment by public or private entities, especially megaproject investments (for example, hydropower, mining, energy extraction, new ports, and satellite cities) that entail population displacement. It is important to distinguish between "construction of risk" that is a universal and transhistorical process in one form or another (Tierney 2014) and malfeasance and corruption by governments (Lewis and Kelman 2012). A good overview of risk creation and its drivers is provided by UNISDR's Global assessment of disaster risk reduction 2013 (UNISDR 2013).

We noted in 2005 that the jobs economic globalization creates may funnel a large number of people into shanty towns, some in coastal cities, and that at the Kobe meeting the impact of free trade agreements on poor and marginal social groups was identified by civil society representatives as the number one risk factor of an increasing number of countries.

Sendai Framework. During the first five years of the SFDRR, the pressure on governments to allow large scale

\footnotetext{
$\overline{9}$ See recommendation 5 in GNDR (2009).
}

investment in hydropower, mining, large scale agribusiness, new technology cities, and luxury housing development has increased. Pressure on indigenous forest dwellers in Brazil's Amazon has increased as has internal displacement of populations (Marchezini and Wisner 2017; Anderson and Elkaim 2018). This is a test of governance. Few governments reject a megaproject on the basis of its possible displacement of people, destruction of livelihoods and the biosphere.

\subsection{Climate Change in the Hyogo and Sendai Frameworks}

Hyogo Framework. In 2005, we asked whether the HFA would effectively integrate efforts to slow climate change and adapt to its effects with the work of agencies that had evolved since the 1950 s to deal with natural hazards as discrete, intense emergencies, as opposed to slow-onset, pervasive and extensive risks. We noted that few countries were doing enough on climate change.

Sendai Framework. The bundling of the SFDRR with other components of the so-called Post-2015 Agenda holds out the hope of integration, coherence, cooperation, and resultant economies of scale and comprehensive translation of knowledge into action. However, so far, the competition for funding and other silo behavior is still common (Kelman et al. 2017). The same frustrating tension between theoretical coherence and real-world institutional politics continues to exist when it comes to linking what are conventionally seen as "development" investments and efforts to reduce disaster risk.

\subsection{War and Disasters as Backdrop to the Hyogo and Sendai Frameworks}

Hyogo Framework. The Indian Ocean tsunami that was the backdrop and elephant in the room throughout the Kobe conference affected some areas where protracted civil wars were taking place. Where there is war, there is little chance of building resilience against disaster. In Aceh, Indonesia and northern Sri Lanka at the time, people were trying to survive wars. As it turned out, the shock of the tsunami and demands of response and recovery supported a peace agreement in Aceh but, sadly, more hostilities in Sri Lanka (Khadka 2019). The Hyogo Framework's implementation faced an uphill struggle for implementation in places where civil wars were on-going such as Colombia and Somalia, and in other places, where organized violence-or at least violent unrest-was the norm.

Sendai Framework. In 2015 and still in 2020, internally displaced people fleeing war live in conditions that make them vulnerable to disaster. Surveying the world suggests that violence and internal displacement is at least as great 
now, as the Sendai Framework attempts to go to scale, as it was then (IDMC 2019a, b). The number of humanitarian workers killed in the line of duty has risen. In 2000, the number was 41, by 2014 deaths had increased to 190, and in 2017 fatalities were lower, but still 139 (UNOCHA 2018, 2020).

\subsection{Urbanization Impacts on Implementation of the Hyogo and Sendai Frameworks}

Hyogo Framework. By 2005, most of world population growth was taking place in urban areas (WHO 2015). This trend persists (United Nations 2019). Moreover, much of this growth is in informal settlements. Many of these rapidly growing cities are on tropical and sub-tropical coasts exposed to storms and sea level rise. Halfway through the HFA implementation period, in 2010, the United Nations International Strategy for Disaster Reduction (UNISDR) launched a "Making Cities Resilient" campaign. By 2015, UNISDR could report that 3400 cities had joined the campaign, 640 had used the "local government self-assessment tool/scorecard" and 334 had used the scorecard "as the basis for creating or adapting urban development plans and taking decisions" UNISDR (2015).

Sendai Framework. The likelihood of creating new risks in the course of investment in cities and urban restructuring is known; the 2013 report of the Sendai Framework's custodian, UNISDR, documented this risk-creation process. ${ }^{10}$ Neither implementation of the SFDRR nor of the UN-Habitat's New Urban Agenda (NUA) ${ }^{11}$ shows evidence of increasing political will by governments to weed out investments that are blind to risk from those that are risk-informed. Nowhere is there mention of vetting or regulating overseas direct investment in cities in the United Nations Office for Disaster Risk Reduction (UNDRR)'s report Making Cities Resilient 2019 (UNISDR 2019), and the "scorecard" used for self-assessment of resilience by cities includes just one item (Policies for location of new developments) among a total of 72 "Example Reference Documents" recommended to provide "Required Information" concerning the scorecard's Ten Essentials (UNDRR 2020b). The main achievements listed in the World Economic Forum's analysis after two years' rollout

\footnotetext{
${ }^{10}$ Chapter 8 of UNISDR's Global Assessment of Disaster Risk Reduction 2013 begins with a very clear statement: "Where investments in urban development generate new risks or exacerbate existing ones, the cost of disasters is often spread across communities and sectors. These shared costs are not well accounted for and responsibilities are not well defined. A number of disincentives work against businesses investing in reducing disaster risk in urban development, including the promise of high profit from speculative investment and ineffective public regulation" (UNISDR 2013).

11 UN-Habitat (2016).
}

of the NUA concern transportation, regional coordination among national governments, and engagement with local governments (Galal 2018).

One driver of "urbanizing risk" is the growing stratification between a new upper middle class and their demands for gated or secure high-rise accommodation, transportation infrastructure, drainage, energy, and other services. This demand has become a profit center for overseas investors who join up with local elites to gentrify neighborhoods. In one extreme case, an entire island city called Eko Atlantic ${ }^{12}$ is being built offshore of Lagos, Nigeria, an investment in part justified as coastal protection from sea level rise. Once complete, this Lagos sibling city will provide high rise apartments, office blocks, shops, and services for a professional class who will no longer have to live among the mass of Nigerians or suffer floods and traffic jams in Lagos. The only problem with this investors' dream is that the development is likely to divert coastal storm surge waters into low income coastal settlements (Onuoha 2017). ${ }^{13}$

An additional challenge to implementing the Sendai Framework in such an urban context is mistrust and alienation. Stratification and increased polarity between the rich and poor breeds mistrust and noncooperation among the residents of self-built, low-income settlements, especially youth (Rocca 2019). Given the SFDRR's commitment to youth participation in DRR, such mistrust and alienation is a serious obstacle to implementation.

\section{Questions Concerning Possible Ways Forward in Hyogo and Sendai Frameworks Implementation}

In preparation for the Kobe Conference, regional assessments were carried out, and the work of national and international nongovernmental organizations and governments was reviewed. Many studies and meta studies were conducted. Various specialized agencies of the United Nations as well as the national societies of the International Red Cross and Red Crescent Federation (IFRC) had been engaged in "disaster risk reduction" avant le mot for many years. Likewise, the United Nations Development Programme (UNDP), Food and Agriculture Organization of the United Nations (FAO), United Nations Children's Fund (UNICEF), World Meteorological Organization (WMO), United Nations High Commissioner for Refugees (UNHCR), and United Nations Environment Programme (UNEP) had experience and portfolios of projects. The

\footnotetext{
$\overline{12}$ https://www.ekoatlantic.com/.

${ }^{13}$ It is ironic that Lagos is a member of the 100 Resilient Cities network (Gusah 2019).
} 
knowledge base was rich. The challenge was to put knowledge into action at scale. A similar large-scale review, a series of regional preparatory conferences, and many studies and reports preceded the conference in Sendai. As I asserted at the beginning of this article, enough knowledge existed then and exists now. The problem is putting it to work. The "way forward" questions Peter Walker and I put to those trying to implement the Hyogo Framework are still highly relevant to the implementation of the Sendai Framework.

\subsection{Local Initiatives and Innovations in the Hyogo and Sendai Frameworks}

Hyogo Framework. The obstacles that face civil society and local government in expanding successes in "bottom up" disaster risk reduction were highlighted in Beyond Kobe. We asked where necessary financial and other essential resources would come from. We wondered how initiatives "from below" can successfully negotiate with subnational and national bureaucracies. Above all, we noted with alarm the delicate relationship between civil society and the state in many countries. In the same year the Hyogo Framework was launched, Robert Mugabe's government in Zimbabwe began its operation Murambatsvina (Drive Out Filth), evicting 700,000 people from selfbuilt homes in Harare, the capital, and began deregistering INGOs and nongovernmental organizations (NGOs) that called attention to human rights abuses in the country (New Humanitarian 2006).

Sendai Framework. The relationship between civil society and the state has been called one of "fierce friends and friendly enemies" (Wisner and Haghebaert 2006). Such tensions have only increased during the Sendai Framework's first five years as social unrest sweeps through many countries. If the SFDRR is truly committed to mobilizing the knowledge and skill of local people, how will it deal with governments if and when they lock out NGOs and other civil society organizations such as faith groups from the decision-making loop?

\subsection{Local Participation in the Hyogo and Sendai Frameworks}

Hyogo Framework. Already shop-worn by 2005, the phrase "local participation" had been common in disaster discourse since at least the mid-term assessment of the International Decade for Natural Disaster Reduction (IDNDR) in May 1994. At that time civil society, UNICEF, and the IFRC demanded that more must be done in the rest of that decade than showcase earthquake engineering tools and models; risk reduction programs must come down to earth and engage with real people. Beyond Kobe pointed out the danger that local initiatives and citizen participation can be captured and controlled by dominant political elites, who already had been quick to appropriate the language of "participation" and "people centered" planning, while giving up no control or resources to civil society.

Sendai Framework. In the era of the Sendai Framework, the risk of cooptation and manipulation of "participation" is greater. Recall what I wrote above about words and how they matter. Note how the new form of words used, especially in the climate change adaptation context, is "community resilience" as well as "responsibility" in the broader domain of disaster management. The danger is that local participation becomes a low-cost way for the state, and the elites it represents, to off-load the duty of care and cost of social protection onto risk bearers themselves. So, while these phrases sound innocent enough, their misuse can produce either cooptation, or an excuse for benign neglect by the state, or both. "Community participation" is subject to the same distortion and misuse.

\subsection{Knowledge and Communication in the Hyogo and Sendai Frameworks}

Hyogo Framework. With 20-20 hindsight, a good deal of expert time was spent at the Kobe conference discussing plans for early warning systems so that a regional tragedy such as the 26 December 2004 Indian Ocean tsunami impact could be avoided in the future. UNISDR tabled a Global Survey of Early Warning Systems at the world conference that launched the HFA, and the conference also saw the parallel launch of an International Early Warning System (United Nations 2005, 2006). The most high-profile, concrete initiative to come out of the latter was establishment of an Indian Ocean Tsunami Warning System. However, national-scale institutional, budgetary, and maintenance problems have reduced its effectiveness (Reuters 2007; Channel News Asia 2018).

Sendai Framework. The role of science and technology loomed large in 2005 and grew to have a dominant place in 2015 with the creation of the SFDRR. In this respect, the glass is half full. As I have stated several times, there is more than enough knowledge in the world to meet the Sendai Framework's modest targets. ${ }^{14}$ The hard part is to

\footnotetext{
${ }_{14}$ SFDRR targets (see https://sendai-resilience.jp/en/sfdrr/): (1) Substantially reduce global disaster mortality by 2030. (2) Substantially reduce the number of affected people globally by 2030. (3) Reduce direct disaster-related economic loss in relation to global gross domestic product (GDP) by 2030. (4) Substantially reduce disaster damage to critical infrastructure related to healthcare and education and disruption to basic utilities by 2030. (5) Increase the number of countries with national and local disaster risk reduction strategies by 2020. (6) Enhance international cooperation to provide adequate and sustainable support for developing nations to enable them to implement the disaster prevention framework by 2020. (7)
} 
get the knowledge used in the right place and the right time. This is sometimes thought of as the "last mile problem": how does a sophisticated system of satellites, ocean buoys, radio transmitters, and computers get a warning to someone in a village on the coast with no mobile phone coverage, no radio, and maybe a bicycle? It can also be thought of as the "first mile problem": how to use local knowledge to design warning systems that are local, relevant, and effective (Gaillard 2018). Progress has been made, for example with the Red Crescent's largescale network of volunteers on the Bangladesh coast who communicate cyclone warning. But this challenge still remains for the SFDRR's implementation.

For the rollout of the Sendai Framework, the question remains if the fixation on technology will be tempered by common-sense, "mud on the boots" appreciation of the life worlds, daily lives and situations, cultures, vernaculars and ways of thinking/communicating that constitute "the first mile" (Krueger et al. 2015).

\subsection{Merging Risk Reduction and Development in the Hyogo and Sendai Frameworks}

Fashions in donor support for "development" change rapidly, depending on the prevailing thinking in centers of power such as the World Bank, the International Monetary Fund, and regional development banks, as well as among the largest donor countries. The world financial system set up at the end of the Second World War has been dominant, but now is challenged by an alternative development bank anchored by China, the emergence of a number of middleincome developing countries, and the BRICS (Brazil, Russia, India, China, and South Africa).

Hyogo Framework. When the HFA came into force as the voluntary guidelines for disaster reduction, the old world-system was still supreme, so the approach to development involved top-down "count-cost-and-carry" implementation of a series of inputs seen as necessary to provide for basic human needs (Wisner 1988). The Kobe conference took place during a period in which programs worldwide were supposed to reduce poverty, increase child survival, expand access to clean water, and so on. These efforts were part of a global commitment to implement the Millennium Development Goals (MDGs), agreed by the UN General Assembly in 2000. Beyond Kobe observed that without identifying specific links between disaster risk reduction and the manner in which the MDGs are being pursued, a key opportunity for concrete implementation

Footnote 14 continued

Substantially increase people's opportunities to access multi-hazard early warning systems and disaster risk information and assessments by 2030 . would be missed, especially because implementation requires bottom-up as well as top-down components.

Sendai Framework. Bundled now with a new set of human development goals (the SDGs), the SFDRR offers a chance simultaneously to reduce risk, adapt to climate change (CCA), and enlarge people's capacities and incomes. What's not to like? What is easy about any of it when the new wine of SDGs, CCA, and DRR might end up funneled into the old wine skins of often corrupt and unaccountable government institutions?

\subsection{Global Alliances of Disaster-Affected Peoples in Hyogo and Sendai Framework Networking}

Hyogo Framework. Our commentary on Kobe and the HFA included a need to forge and extend global alliances. The Kobe conference itself saw one of these created as a response by civil society to weaknesses in the Hyogo Framework itself. This was the Global Network of Civil Society Organisations for Disaster Reduction (GNDR). ${ }^{15}$ More generally, the period of HFA's implementation saw an increase in the visibility of civil society in discussions of disaster reduction at national and international scales.

Sendai Framework. The SFDRR, if implemented, will deepen relations with civil society. The global surveys conducted by GNDR are called Views from the Front Lines (GNDR 2019). They were at one time principally tools for holding the custodian of the Hyogo Framework (UNISDR) and the HFA's signatory governments to account as well as provide a counterpoint to the Hyogo Framework's accounting tool (the HFA Monitor). Now these surveys are also being used as an integral part of the Sendai Monitor.

Still more global networking is required, especially at a time when new nationalisms and more walls (physical and psychological) are dividing people. I repeat what we wrote in Beyond Kobe: that UNDRR should combine efforts with networks surrounding the World Social Forum as well as make connections with trade unions. Teachers, sanitary workers, water engineers, nurses and other health professionals, and construction workers are often unionized. Such workers have an organic material interest in safety and also have developed skill and knowledge in safe job performance. Their apex union federations at the national level would make valuable partners in implementing the SFDRR.

\subsection{Women's Crucial Role in Disaster Reduction in the Hyogo and Sendai Frameworks}

Hyogo Framework. The Beyond Kobe evaluation noted that the HFA still did not recognize the full capacity of women

\footnotetext{
$\overline{15}$ https://www.gndr.org/.
} 
as agents of history and as leaders, ${ }^{16}$ and its implementation did not result in sharing power and control with women and girls. Then, as also now, there are still those who think of women and children only as victims and as those who suffer most in disasters (although the evidence is mixed). They are thought of as a category such as "high risk," and at best, project or program funding is set aside or even ring-fenced so that their "special needs" are met in response and recovery.

Sendai Framework. During SFDRR's first five years, moves are underway to filter data by gender and age for damage assessments and for preparedness and risk reduction planning (Bradshaw and Fordham 2013; Seager 2014) and to monitor impacts of climate change policy for their possible negative effects on women and girls (Habtezion 2016). Women have also gained recognition as skillful and capable leaders in DRR (UN Women 2019). Nevertheless, there remains a danger of essentializing women by emphasizing their "caring" role as a function of a "natural" division of labor. Also insidious is the assumption that women's labor in DRR is a free good that needs no support from the state. This is a variation on the trap of "community resilience" as shorthand for the neo-liberal state's shedding the duty of care and dispensing with social protection, while relying on individual responsibility and group self-help.

\subsection{Full National Accountability and Transparency in the Hyogo and Sendai Frameworks}

Hyogo Framework. The Hyogo Framework's implementation did not include targets, timetables, or indicators of success in putting the "framework" for disaster risk reduction to work concretely on the ground. The HFA Monitor merely reproduced the self-assessment of governments on a scale of 1-5 of "achievement" of very general goals (UNISDR nd). There were no detailed targets. There was no fact-checking by UNISDR of the accuracy of what governments reported. Governmental efforts and achievements will be more systematically recorded and comparable by the Sendai Monitor. ${ }^{17}$ In addition, GNDR is currently establishing a grassroots baseline that will act as a reality check and also enrich the reporting that countries provide to UNDRR (GNDR 2020).

Sendai Framework. There is more to successful implementation than the fulfilment of countable targets. If, as I have been arguing, neither the Hyogo Framework nor the

\footnotetext{
16 The scholarship devoted to overturning the myth of victimhood and documenting women's (and children's and youth's) proactive contributions to health, safety, and risk reduction is very large. A good guide to resources is available on the website of the Gender and Disaster Network http://www.gdnonline.org/.

17 https://sendaimonitor.unisdr.org/.
}

Sendai Framework encourages governments to think of disaster reduction in terms of human rights, or challenges governments to stand up to private investors concerning megaprojects that threaten to create new risk, more is required. Thus "bean counting"-while improved in SFDRR's case-will not reveal the underlying issues that still need to be addressed.

Until recently UNISDR/UNDRR's various global assessments of disaster reduction (GARs) placed such issues on the agenda. Recent administrative changes in UNISDR that gave rise to UNDRR (new name and new administrative team) may also have muted internal dissent and self-criticism. The team that produced those earlier GARs has been dispersed, and a new team has taken over. Judging from the first report by the new team (UNDRR $2019 \mathrm{~b}$ ) it is hard to say if their independence and courage will be equivalent. A series of GARs provided analysis that highlighted issues that were not commonly acknowledged by governments as having anything to do with disaster risk (UNISDR 2009, 2011b, 2013). These included the impact of gentrification and megaprojects on urban populations who are either displaced or suffer living in proximity to new hazards. My first impression is that the GAR has become a "house organ" of the UNDRR rather than an independent report created by a semiautonomous team that bores deeply into underlying risk factors. Time will tell how the GAR develops under new management.

\section{Conclusion and Challenge to the United Nations Office for Disaster Risk Reduction}

The Sendai Framework breaks the pattern of the decadelong time scales for major UN initiatives. The UN has given governments and itself a leisurely 15 years, until 2030, to achieve their modest goals. Let's consider for a moment the most recent IPCC-based scenarios for 2030 . The world's average temperature has already increased $1^{\circ} \mathrm{C}$ above the pre-industrial average. We have already seen coral bleaching, sea-level rise, more intense cyclonic storms, and increased intensity and frequency of wildfires. At $1.5^{\circ} \mathrm{C}$, on the best-case scenario, we will expect even more intense storms, ecosystem transformation, considerable ocean fishery decline, increased sea-level rise, deadly heat waves and other effects. So, the Sendai Framework will be reporting to humanity in 2030 in an air-conditioned conference center far from a coast. Just to achieve that blissful state, and not overshoot global warming of $1.5^{\circ} \mathrm{C}$ the IPCC's 2018 report says would require (IPCC 2018):

rapid and far-reaching transitions in energy, land, urban and infrastructure (including transport and buildings), and industrial systems [...]. These 
systems transitions are unprecedented in terms of scale, but not necessarily in terms of speed, and imply deep emissions reductions in all sectors."

Each and every one of the massive energy, land, urban, and infrastructure transformations called for by the IPCC carries with it the potential for displacement of people and dislocation of their livelihoods, hence potentially increased vulnerability to the hazards already inevitable at $1.5{ }^{\circ} \mathrm{C}$ warming. There is, thus, the potential for risk creation in the course of the economic transformations required to avoid even more harmful global warming. The sheer scale and speed of the necessary transformation increase the chance that already marginalized people will suffer.

An additional challenge to the UN, and in particular to the UNDRR, is to guide governments to go beyond superficial coordination in their rollout of each national version of the Post-2015 Agenda and to achieve full integration. The SFDRR, the New Urban Agenda, and the transformations required to slow climate change must be implemented rapidly and in such an integrated manner that such negative consequences as new risk creation and further marginalization are flagged and avoided.

UNDRR, as custodian of the SFDRR, should claim a role as the conscience of global energy transformation and watchdog of the comprehensive transformation that is required to take the worst hurt out of climate change as well as simultaneously achieving SFDRR's own goals and those of the other initiatives comprising the Post-2015 Agenda. If UNDRR is fit for this purpose, it is by fortuitous accident. Its roots lie in the early efforts to reduce disaster spearheaded by UNDRO as early as 1971, through interagency International Decade of Natural Disaster Reduction (IDNDR) and the more recent institutions under OCHA including UNISDR and the current UNDRR. Over nearly five decades, large, overlapping communities of disaster risk knowledge and practice have evolved, and experience has been gained in partnerships among many international actors including UNESCO, ILO, UNEP, UNDP, WMO, FAO, WHO, PAHO, WB, IFRC, and many others. UNDRR is the product of many years of collaboration and knowledge sharing as the UN system developed capacity to understand disaster risk, one health (human, plant and animal), human well-being, happiness and security, and, more recently, climate change. Of course, these efforts also produced silos, career paths, and dedicated budgets: hence jealousies and competition. Yet knowledge was shared and a basis for moving from competition to cooperation is there.

Importantly, as noted already, the role of civil society has increased through the years of guidance by the HFA and the first five years of SFDRR. It would be possible to issue early warning of risk creation and to clarify and to articulate the needs of those already marginalized, by pushing and transcending the limits of established partnerships while increasing assistance to civil society and amplifying its voice. Already researchers and INGOs have called attention to the perils of new risk creation in a warming world of increasing wealth and income disparity. They have also exposed profiteering and land grabs justified by the imperatives of "risk reduction" and "the climate adaptation imperative" (Smucker et al. 2015). The UNDRR should listen carefully to these partners and amplify their warnings. This new and radically proactive and pro-poor leadership role for UNDRR in partnership with civil society requires action now.

We do not have the time for the gentle diplomatic stroll toward a series of midterm reports, assessments, more consultants' reports, and conferences. We do not have time for diplomatic care not to tread on another agency's conventional mandates. If the Sendai Framework is serious, and if the whole Post-2015 Agenda is to accomplish anything, then governments must stop protecting narrow elite interests, listen to the crescendo of protest rising to their air-conditioned offices from the over-heated streets, and adopt a rights- and justice-based transformation that will allow the overthrow of special interests and the rapid transformations that are needed.

Open Access This article is licensed under a Creative Commons Attribution 4.0 International License, which permits use, sharing, adaptation, distribution and reproduction in any medium or format, as long as you give appropriate credit to the original author(s) and the source, provide a link to the Creative Commons licence, and indicate if changes were made. The images or other third party material in this article are included in the article's Creative Commons licence, unless indicated otherwise in a credit line to the material. If material is not included in the article's Creative Commons licence and your intended use is not permitted by statutory regulation or exceeds the permitted use, you will need to obtain permission directly from the copyright holder. To view a copy of this licence, visit http://creativecommons. org/licenses/by/4.0/.

\section{References}

Anderson, M., and A. Elkaim. 2018. Belo Monte legacy: Harm from Amazon dam didn't end with construction. Mongabay, 23 February 2018. https://news.mongabay.com/2018/02/belomonte-legacy-harm-from-amazon-dam-didnt-end-with-construc tion/. Accessed 2 Sept 2019.

Bradshaw, S., and M. Fordham. 2013. Women, girls and disaster: A review for DFID. London: Department for International Development.

Braine, T. 2006. Was 2005 the year of natural disasters? Bulletin of the World Health Organization 84(1): 4-8.

Channel News Asia. 2018. Indonesia's tsunami buoy warning system not working since 2012. Channel News Asia, 24 December 2018. https://www.channelnewsasia.com/news/asia/indonesia-tsunamibuoy-warning-system-not-working-since-2012-11059044. Accessed 16 Dec 2019. 
Chmutina, K., and J. von Meding. 2019. A dilemma of language: "Natural disaster" in academic literature. International Journal of Disaster Risk Science 10(3): 283-292.

Economist. 2013. The origins of the financial crisis: Crash course. The Economist, 7 September. https://www.economist.com/schoolsbrief/2013/09/07/crash-course Accessed 23 Nov 2019.

Gaillard, J.C., and I. Kelman. 2018. The first mile of warning systems: Who's sharing what with whom? Humanitarian Practice Network, 8 November 2018. https://odihpn.org/blog/first-mile-warn ing-systems-whos-sharing/. Accessed 4 Dec 2019.

Galal, H. 2018. How much progress has been made on the New Urban Agenda? World Economic Forum, 31 October 2018. https:// www.weforum.org/agenda/2018/10/how-much-progress-hasbeen-made-on-the-new-urban-agenda/. Accessed 21 Dec 2019.

Gibson, T. 2019. Making aid agencies work. London: Emerald.

GNDR (Global Network of Civil Society Organisations for Disaster Reduction). 2009. "Clouds but little rain..." Views from the frontline 2009. London: GNDR. https://www.gndr.org/pro grammes/views-from-the-frontline/vfl-2009.html. Accessed 2 Dec 2019.

GNDR (Global Network of Civil Society Organisations for Disaster Reduction). 2019. Views from the frontline. https://www.gndr. org/programmes/views-from-the-frontline.html. London: GNDR. Accessed 25 Jan 2020.

GNDR (Global Network of Civil Society Organisations for Disaster Reduction). 2020. Frontline and local monitoring of post 2015 frameworks. Frontline. London: GNDR. https://www.gndr.org/ component $/ \mathrm{k} 2 /$ itemlist/category $/ 194 . \mathrm{html}$ ?Itemid=201. Accessed 25 Jan 2020.

Gusah, S. 2019. Charting a resilient path forward for Lagos. 100 Resilient Cities, 18 February 2019. http://www.100resilientcities. org/charting-resilient-path-forward-lagos/. Accessed 25 Jan 2020.

Habtezion, S. 2016. Gender and disaster. New York: UNDP and Global Gender and Climate Alliance.

IDMC (International Displacement Monitoring Center). 2019a. Global report on internal displacement 2019. Geneva: IDMC. http://www.internal-displacement.org/global-report/grid2019/. Accessed 14 Jan 2020.

IDMC (International Displacement Monitoring Center). 2019b. Global internal displacement database ("Total annual new displacements since 2003 (conflict and violence) and 2008 (disasters)" and "number of IDPs and refugees, 1990-2018"). Geneva: IDMC. http://www.internal-displacement.org/database/ displacement-data. Accessed 14 Jan 2020.

IPCC (Intergovernmental Panel on Climate Change). 2018. Headline statements. https://www.ipcc.ch/sr15/resources/headline-state ments/. Accessed 25 Jan 2020.

Jerolleman, A. 2019. Disaster recovery through the lens of justice. Cham, Switzerland: Palgrave Pivot.

Kashambuzi, E. 2013. The role of peace and security in the post-2015 agenda: Perspective of African states and LDCs. New York: Center on International Cooperation, New York University. https://cic.nyu.edu/blog/global-development/role-peace-andsecurity-post-2015-agenda-perspective-african-states-and-ldcs. Accessed 13 Nov 2019.

Kelman, I., J. Mercer, and J.C. Gaillard (eds.). 2017. Routledge handbook of disaster risk reduction including climate change adaptation. New York: Routledge.

Kent, G. 2001. The human right to disaster mitigation and relief. Environmental Hazards 3(3):137-138.

Krueger, F., G. Bankoff, T. Cannon, B. Orlowski, and E.L. Schipper. 2015. Cultures and disaster. London: Routledge.

Khadka, N. 2019. Refugees at "increased risk" from extreme weather. $B B C, 10$ December 2019. https://www.bbc.com/news/ science-environment-50692857. Accessed 16 Jan 2020.
Klein, N. 2008. Shock doctrine: The rise of disaster capitalism. New York: Picador.

Klein, N. 2018. The battle for paradise: Puerto Rico takes on the disaster capitalists. New York: Haymarket.

Lewis, J., and I. Kelman. 2012. The good, the bad and the ugly: Disaster Risk Reduction (DRR) versus Disaster Risk Creation (DRC). PLOS Current Disasters. https://doi.org/10.1371/ $4 \mathrm{f} 8 \mathrm{~d} 4 \mathrm{eaec6af8.}$

Lindsay, J. 2015. The world events that mattered most in 2015. The Atlantic, 22 December 2015. https://www.theatlantic.com/inter national/archive/2015/12/world-events-news-2015/421545/. Accessed 12 Sept 2019.

Marchezini, V., and B. Wisner. 2017. Challenges for vulnerability reduction in Brazil: Insights from the PAR framework. In Reduction of vulnerability to disasters: From knowledge to action, ed. V. Marchezini, B. Wisner, L. Londe, and S. Saito, 57-96. Sao Carlos, Brazil: RiMa Editores.

New Humanitarian. 2006. Zimbabwe: A year after urban purge, conditions for displaced still grim. The New Humanitarian, 8 May 2006. https://reliefweb.int/report/zimbabwe/zimbabweyear-after-urban-purge-conditions-displaced-still-grim. Accessed 4 Oct 2019.

O'Keefe, P., K. Westgate, and B. Wisner. 1976. Taking the "natural" out of "natural disaster". Nature 260(5552): 566-567.

Oliver-Smith, A., I. Alcántara-Ayala, I. Burton, and A. Lavell. 2016. Forensic investigations of disasters (FORIN): A conceptual framework and guide to research. Beijing: Integrated Research on Disaster Risk (IRDR).

Onuoha, M. 2017. A 5-mile island built to save Lagos's economy has a worrying design flaw. Quartz Africa, 18 March 2017. https:// qz.com/africa/923142/the-flaw-in-the-construction-of-eko-atlan tic-island-in-lagos. Accessed 14 Nov 2019.

Peters, K., and T. Tanner. 2016. Resilience across the post-2015 frameworks: How to create greater coherence. London: Overseas Development Institute.

Potetee, A., and J. Ribot. 2011. Repertoires of domination: Decentralization as process in Botswana and Senegal. World Development 39(3): 439-449.

Reuters. 2007. Batteries need to be changed: $80 \mathrm{pc}$ of Thailand's tsunami warning system needs maintenance. Reuters, 31 July 2007. https://www.scmp.com/news/asia/southeast-asia/article/ 2104777/batteries-need-be-changed-80pc-thailands-tsunamiwarning. Accessed 6 Dec 2019.

Rocca, F. 2019. To repair trust, we have to listen and then act. The New Humanitarian, 6 December 2019. https://www.thenewhumanitarian.org/opinion/2019/12/6/aid-workers-trust?utm_source $=$ twitter\&utm_medium $=$ social\&utm_campaign $=$ social\&utm_source $=$ The + New + Humanitarian\&utm_campaign $=$ 9295532661-EMAIL_CAMPAIGN_12_6_2019\&utm_medium $=$ email\&utm_term $=0$ _d842d98289-929553266175426061. Accessed 23 Dec 2019.

Saechao, T. 2007. Natural disasters and the responsibility to protect: From chaos to clarity. Brooklyn Journal of International Law 32(2): Article 9.

Saunders, W., S. Kelly, S. Paisley, and L. Clarke. 2020. Progress toward implementing the Sendai Framework, the Paris Agreement, and the Sustainable Development Goals: Policy from Aotearoa New Zealand. International Journal of Disaster Risk Science 11(2). https://doi.org/10.1007/s13753-020-00269-8.

Seager, J. 2014. Disasters are gendered: What's new? In Reducing disaster: Early warning systems for climate change, ed. A. Singh, and Z. Zommers, 265-281. Cham, Switzerland: Springer Nature.

Smucker, T., B. Wisner, A. Mascarenhas, P. Munishi, E. Wangui, G. Sinha, D. Weiner, C. Bwenge, and E. Lovell. 2015. Differentiated livelihoods, local institutions, and the adaptation 
imperative: Assessing climate change adaptation policy in Tanzania. Geoforum 59: 39-50.

Tierney, K. 2014. The social roots of risk. Stanford, CA: Stanford Business Books.

UN (United Nations). 2005. UN launches plan for global early warning system for natural disasters. UN News, 19 January 2005. https://news.un.org/en/story/2005/01/126192-un-launches-plansglobal-early-warning-system-natural-disasters. Accessed 14 Dec 2019.

UN (United Nations). 2006. Global survey of early warning systems. Report prepared at the request of the Secretary General. New York: United Nations. https://www.unisdr.org/we/inform/publi cations/3612. Accessed 14 Dec 2019.

UN (United Nations) 2013. General Assembly (A/68/202). A life of dignity for all: Report of the Secretary General. Follow-up to the Millennium Summit. New York: United Nations.

UN (United Nations). 2019. The world's cities 2018. New York: United Nations.

UNDRR (United Nations Office for Disaster Risk Reduction). 2019a. Global platform for disaster risk reduction 2019: ProceedingResilience dividend: Towards sustainable and inclusive societies. Geneva: UNDRR. https://reliefweb.int/report/world/glo bal-platform-disaster-risk-reduction-2019-proceedings-resili ence-dividend-towards. Accessed 14 Oct 2019.

UNDRR (United Nations Office for Disaster Risk Reduction). 2019b. Global Assessment Report 2019. Geneva: UNDRR. https://gar. unisdr.org/report-2019. Accessed 23 Dec 2019.

UNDRR (United Nations Office for Disaster Risk Reduction). 2020a. The International Decade for Natural Disaster Reduction (IDNDR). https://www.preventionweb.net/organizations/2672. Accessed 5 Nov 2019.

UNDRR (United Nations Office for Disaster Risk Reduction). 2020b. Reference note on required data/information. In Disaster resilience scorecard for cities preliminary \& detailed assessments. Geneva: UNDRR https://www.unisdr.org/campaign/resi lientcities/toolkit/article/disaster-resilience-scorecard-for-cities. Accessed 13 Jan 2020.

UN-Habitat (United Nations Human Settlements Program). 2016. The new urban agenda. Nairobi: UN-Habitat. http://www.habitat3. org/the-new-urban-agenda/. Accessed 25 Jan 2020.

UNISDR (United Nations International Strategy for Disaster Reduction). nd. National HFA monitor. https://www.preventionweb. net/english/hyogo/hfa-monitoring/national/. Accessed 17 Dec 2019.

UNISDR (United Nations International Strategy for Disaster Reduction). 2009. Global assessment of disaster risk reduction 2009. Geneva: UNISDR.

UNISDR (United Nations International Strategy for Disaster Reduction). 2011a. Third world conference on disaster reduction, preparatory process. https://www.wcdrr.org/preparatory. Accessed 25 Aug 2019.

UNISDR (United Nations International Strategy for Disaster Reduction). 2011b. Global assessment of disaster risk reduction 2011. Geneva: UNISDR.

UNISDR (United Nations International Strategy for Disaster Reduction). 2013. Global assessment of disaster risk reduction 2013. Geneva: UNISDR. https://www.preventionweb.net/english/ hyogo/gar/2013/en/home/index.html. Accessed 25 Aug 2019.
UNISDR (United Nations International Strategy for Disaster Reduction). 2015. About the campaign. In Making cities resilient: My city is getting ready. Geneva: UNDRR. https://www.unisdr.org/ campaign/resilientcities/about/article/about-the-campaign. Accessed 4 Oct 2019.

UNISDR (United Nations International Strategy for Disaster Reduction). 2019. Making cities resilient report 2019. Geneva: UNISDR.

UNOCHA (United Nations Office for the Coordination of Humanitarian Affairs). 2018. Aid workers killed. New York: UNOCHA. https://www.unocha.org/story/aid-worker-deaths-numbers-tellstory. Accessed 5 Oct 2019.

UNOCHA (United Nations Office for the Coordination of Humanitarian Affairs). 2020. Aid worker security map. New York: UNOCHA. http://archive.irinnews.org/aid-worker-security-map/ dataviz.html. Accessed 3 Jan 2020.

UN Women. 2019. Promoting women's leadership in disaster risk reduction and resilience. https://www.unwomen.org/en/news/ stories/2019/5/news-promoting-womens-leadership-in-disasterrisk-reduction-and-resilience. Accessed 16 Dec 2019.

Vogler, V., and M. Hammond. 2017. Who should pay for damage associated with climate change - and who should be compensated. The Conversation, 18 September 2017. https://theconversa tion.com/who-should-pay-for-damage-associated-with-climatechange-and-who-should-be-compensated-84028. Accessed 7 Oct 2019.

WHO (World Health Organization). 2015. Urban population growth. Global Health Observatory, 2015. https://www.who.int/gho/ urban_health/situation_trends/urban_population_growth/en/. Accessed 1 Jan 2020.

Wisner, B. 1988. Power and need in Africa. London: Earthscan.

Wisner, B., and B. Haghebaert. 2006. Fierce friends/friendly enemies: State/civil society relations. Paper presented at ProVention Consortium Forum 2006, 2-3 February 2006, Bangkok, Thailand.

Wisner, B., and P. Walker. 2005a. Beyond Kobe: A proactive look at the World Conference on Disaster Reduction, 18-22 January 2015, Kobe, Japan. A Report for the Swiss Department of Humanitarian Aid. Medford, MA: Feinstein International Famine Center, Friedman School of Nutrition Science and Policy, Tufts University.

Wisner, B., and P. Walker. 2005b. The world conference on disaster viewed through the lens of political ecology: A dozen big questions for Kobe and beyond. Capitalism, Nature, Socialism 16(2): 85-95.

Wisner, B., P. Blaikie, T. Cannon, and I. Davis. 2004. At risk: Natural hazards, people's vulnerability and disasters, 2nd edn. London: Routledge.

Wisner, B., J.C. Gaillard, and I. Kelman (eds.). 2012. The Routledge handbook of hazards and disaster risk reduction. London: Routledge.

World Bank. 2010. Natural hazards, unnatural disasters: The economics of effective prevention. Washington, DC: World Bank. https://openknowledge.worldbank.org/handle/10986/ 2512. Accessed 23 Nov 2019. 